\title{
COMPARATIVE ANALYSIS OF THE SOMATIC PHRASEOLOGICAL UNITS OF THE ENGLISH AND RUSSIAN LANGUAGES WITH THE COMPONENT "HEART"
}

\author{
Dona Sotvoldievna Usmonova \\ Fergana State University, Uzbekistan \\ Marjona Ikromjon Qizi Yusupova \\ Fergana State University, Uzbekistan
}

\section{ABSTRACT}

This article demonstrates peculiarities of somatic phraseological units both Russian and English languages and gives the results of a comparative investigation of somtisms with the component "heart". Linguocultural aspect of linguistics has been taken into consideration while doing research on comparing phraseological units of the languages. Paremia has been emphasized as a significant component of the conducted analysis.

KEYWORDS: - Somatism, linguoculturology, paremia, phraseological units, metaphor, comparative research, paremiological units, lexico-thematic system, semantics, polysemy.

\section{INTRODUCTION}

Somatic vocabulary (from the Greek "soma" "body") - one of the lexical groups in any language and the most common object of study in comparative historical, linguocultural works of domestic and foreign linguists who usually highlight this vocabulary first in the lexico-thematic system of any language.

Somatics - nouns with the original meaning of parts human or animal body. Somatic vocabulary means such units whose constituent components are words -names of parts of the human body, body of animals. This term can be used in biology, medicine in the sense of "something related with the human body" and is contrasted with the concept of "psychic".

At the end of the XX - beginning of the XXI centuries, linguists pay special attention to somatic vocabulary, trying to find tolerant solutions to problems intercultural communication, increase the effectiveness of the study of the lexical composition of the language. This term was first introduced by F.O. Wac. He concluded that "somatics refers to one of the most ancient layers of phraseology and constitute the most used of the vocabulary of any language"[1]. So, from the second half of XX, the term "somatic" is actively used in word research, which denotes everything that belongs to the body of a person or animal.

The interest of linguists in somatics is explained by 
CURRENT RESEARCH JOURNAL OF PHILOLOGICAL SCIENCES 2(11):

94-99, November 2021

DOI: https://doi.org/10.37547/philological-crjps-02-11-21

ISSN 2767-3758

(C)2021 Master Journals

\section{Crosser do) (81" Google}

Accepted $25^{\text {th }}$ November, 2021 \& Published $30^{\text {th }}$ November, 2021

the fact that the process of awareness of oneself as a person, a person began with sensations that arise through the senses and parts of his own body. "A person is egocentric, - writes V.G. Gak in one of his last works - he sees in himself the center of the universe and displays the world in its own likeness "[2]. It is known that all people in the world, of any nationality, can such parts of your body as head, leg, eye, ear, and so on.

Somatics represents a range of necessary in any human society of concepts and relationships, without which it is difficult to imagine human speech, and notes that somatic vocabulary is distinguished by a high frequency of use and developed polysemy. Somatic vocabulary is a holistic system that has a constant number of objects of nominations and it is intended for the designation of a specific composition of a lexical unit. The first indicator is extralinguistic, that is, referring to real reality, in which language develops and functions, is not depends on the national language, and the second is in direct proportion from the individual characteristics of a particular language: composition the corresponding lexemes can differ both in quantitative and in qualitatively. The heart is the main and central human organ. The inner world of a person is always focused on the heart. In Russian and English paremias, this somatism most often symbolizes such human emotions as experiences, joy, love, sorrow, and so on. In Russian and English explanatory dictionaries, we have found the following definitions characterize the words heart / сердце.

The most basic are the values shown in the table below.

\begin{tabular}{|l|l|}
\hline \multicolumn{1}{|c|}{ Heart } & \multicolumn{1}{|c|}{ Сердце } \\
\hline $\begin{array}{l}\text { 1) A hollow muscular organ that pumps the } \\
\text { blood through the circulatory system by } \\
\text { rhythmic contraction and dilation. }\end{array}$ & $\begin{array}{l}\text { Центральный орган кровеносной системы } \\
\text { располагающийся в левой стороне груди } \\
\text { человека. }\end{array}$ \\
\hline $\begin{array}{l}\text { 2) The heart is regarded as the center of a } \\
\text { person's thoughts and emotions, especially } \\
\text { love or compassion. }\end{array}$ & $\begin{array}{l}\text { Ұуа часть тела как символ средоточия } \\
\text { человека. }\end{array}$ \\
\hline 3) The central or innermost part of something. & $\begin{array}{l}\text { Важнейший пункт, место, имеющее } \\
\text { существенное значение для чего-нибудь, } \\
\text { средоточие чего-нибудь. }\end{array}$ \\
\hline
\end{tabular}

After examining these values, we can conclude that English and Russian definitions coincide with each other. We analyzed 119 proverbs, of which 76 are Russian, 43 - English. We found that in the Russian language "heart" in its primary meaning was used in 12 proverbs, which is 21\%, while in English - 12 proverbs $-27 \%$.[3]

We found out that in Russian paremias, the heart in 
CURRENT RESEARCH JOURNAL OF PHILOLOGICAL SCIENCES 2(11):

94-99, November 2021

DOI: https://doi.org/10.37547/philological-crjps-02-11-21

ISSN 2767-3758

(C)2021 Master Journals

Crossref do

gil Google

Accepted25 th November, 2021 \& Published 30 ${ }^{\text {th }}$ November, 2021

its original meaning is defined using adjectives such as painful (1), human (1), falcon (1), sick (1). In English paremiology, the lexeme heart in a somatic meaning is defined with adjectives such as human (2) - human, big (1) - big, sick (1) - sick, stout (1) strong.

In the English language, a significantly larger number of paremias are revealed, expressing the attitude of native speakers to a kind, responsive heart.

We also considered cases where affiliation was expressed given somatism: woman's heart (1) сердце женщины, man's heart - сердце мужчины. In Russian and English paremiology, considering this somatism as the subject of the action forms verb combinations and can describe the state of a person, his feelings, experiences, mood, pain Feel. For example, in Russian somatism the head is used with with such verbs as lie (2), torture (1), wait (1), hurt (3), suffer (2), have fun (1), boil (1), know (2), protect (1), warm (1). In English paremias, the word heart is used with verbs - to grieve over (1) скорбеть, to give (1) - давать, to go -идти, следовать, to beat (1) - стучать, to grow (1) расти, to love (1) - любить, to ache - болеть, to think (1) - думать, to break - повреждать, ломать. In several Russian and English paremias, сурдце and heart can be used in a metaphorical sense. In Russian paremias actively used metaphors to convey human qualities. For example, «черствое сердце» says that a person is evil, cruel, «большим сердцем» is possessed by a sincere, moral, humane person. Such an expression like «горя сердца не вымучить», «печаль съедает сердце» can hide the meaning of an unbearably difficult condition from mental pain person. «Принимать сердцем», «чуять сердцем», «любить сердцем», suggests that this is the "organ" of love affection. In English proverbs and sayings have also been identified with the metaphorical meaning given somatism. "Happy heart" denotes a person's mood, "warm heart "," light heart "- its positive qualities, like kindness, sincerity, while "faint heart" denotes the insecurity, weakness of the human character, "heart of wax" denotes a person's indifference to what is happening, to some unpleasant events.

In Russian paremias, «сердце» component carries a negative shade when a person refuses to manifest reason. For example: Не давай воли языку во пиру, а сердцу в гневе; Молодецкое сердце неуклончивое.

Russians believed that human health depends on the state of mind, therefore, in Russian paremias, emotional experiences are often reflected, negative emotions that affect a person's well-being. For example: Всякая болезнь к сердцу; Ревность, что ржа, губит сердца. You can see that in Russian paremias using the heart component reflects the emotional alienation of the sick and healthy when a healthy person did not show a feeling of compassion for the sick person. For example: He всякому болезнь чужая по сердцу входит; не всякая печаль чужая в жалость вводит.

Russian paremias with the word heart also reflect the attitude towards flattery. Flattery was always condemned, they showed distrust of a flattering person and neglect. The man who could not tell the difference between flattery and praise was considered weak, weak-willed, not knowing his worth. For example: В сердце льстец всегда отыщет уголок; На языке медок, а на сердце ледок. The soul is the most important category of Russian consciousness. It describes the largest number of Russian language paremias with a component heart. The heart reflects the soul of a person, his emotions, passions, experiences, temper, mood. For example: Дай сердцу волю приведет в неволю; У кого на сердце ненастно, у того и на всякий день дождь. 
CURRENT RESEARCH JOURNAL OF PHILOLOGICAL SCIENCES 2(11):

94-99, November 2021

DOI: https://doi.org/10.37547/philological-crjps-02-11-21

ISSN 2767-3758

(C)2021 Master Journals

Crossref doi

gil Google

Accepted25th November, 2021 \& Published 30th November, 2021

evil.

In English pairs with a heart component, it most often describes the emotional feeling of sadness, sadness with the help of a metaphorized adjective broken - broken, broken. For example, A broken heart mends quickly when repair; Nobody dies of a broken heart. The feeling of joy in English paremias is transmitted through the heart component appears light, light, it decorates and simplifies the life of every person. For example, A light heart lives long; A light heart makes light work; a Blithe heart makes a blooming visage. Into English paremias, there is an attitude towards such a deep feeling as sincerity in any situation, especially when a person turns to God. For example: If your heart is in your prayer, God will know.

In English paremias, with the help of somatism, the heart is very often such a human quality as courage is reflected. The heart is a source of strength and courage. For the "English heart" such qualities as determination, courage, and will are required. In their opinion, a brave person always has good luck: To a brave heart, nothing is impossible; A stout heart crushes ill luck.

However, in English paremias, the cowardice of the heart is condemned and ridiculed by native speakers: Faint heart sleeps alone; Faint heart never won. In English paremias, the somatism of the heart can be compared with the inner fire of a person who carries aggression, passion, pulse. For example: When the heart is a fire, some sparks will fly out through the mouth. The heart is also the center of love, compassion, spirituality. Love in Russian couples with a heart component is revealed as $\mathrm{s}$ spiritual attachment, uncontrollable, deep, strong emotional feeling. For example, В сердце не влезешь; Сердце сердце чует; Будешь любить, коли сердце болит. In Russian paremias, the heart can reflect human willfulness, anger, hatred, anger, hypocrisy; reflect the conflict between good and
For example: Сердце душу бережет и душу мутит; Гнило слово от гнила сердца; В сердцах иных людей всегда сумерки. Russians believed that human health depends on the state of mind, therefore, in Russian paremias, emotional experiences are often reflected, negative emotions that negatively affect well-being human component, also with the help of somatism, the heart is reflected feeling of compassion, feelings for sick people, negative attitude towards flattery. The heart reflects the soul of a person, his emotions, passions, feelings, temper, mood. The feeling of joy in English pariahs transmitted using the heart component, appears light, light, the attitude towards such a deep feeling as sincerity is also conveyed, especially when a person turns to God. In English paremias using somatism heart very often reflects such a human quality as courage, where the heart is the source of strength and courage, while cowardice of the heart is condemned and ridiculed by native speakers. In English paremias, the somatism of the heart can be compared with the inner by the fire of a person who carries aggression and passion. The heart is also the center of love, compassion, spirituality. Love in Russians and English paremias with the heart component is revealed as a spiritual affection, uncontrollable, deep, strong emotional feeling.

In the Russian language, there are much more paremias with this somatism than in English. In English paremias, the concept of the heart in its primary meaning is much more common. This somatism, as a subject of action, can describe the state of a person, his feelings, experiences, mood, and painful sensations. In several Russian and English paremias, this somatism can be used metaphorically to convey human qualities, feelings, emotions. 
CURRENT RESEARCH JOURNAL OF PHILOLOGICAL SCIENCES 2(11):

94-99, November 2021

DOI: https://doi.org/10.37547/philological-crjps-02-11-21

ISSN 2767-3758

(C)2021 Master Journals

\section{Crossref do) 81 Google}

Accepted25 $5^{\text {th }}$ November, 2021 \& Published $30^{\text {th }}$ November, 2021

Somatisms - nouns with the original meaning of parts human or animal body. This term can be used in biology, medicine in the meaning of "something related to the human body" and is contrasted with the concept of "psychic". A human being realizing himself as a personality begins with the sensations that appear through his organs feelings and parts of his body.

Since then, as a person began to be aware of himself and the world around him, the phenomenon of a picture of the world arose. The picture of the world is an ordered body of knowledge about reality. With the help of the senses and abstract thinking, a person learns the world, forming a given picture of the world. Modern linguistics pays more and more attention to observing the connections between man and language. Language is a means of expression and storing people's ideas about the world around them. These views and the images include many spheres that gather in a kind of picture of the world. The language picture of the world is called historically formed in the objective consciousness of a person, the totality of some views or ideas about the world that are reflected in the language of any ethnos.

The variety of phenomena, observed and imagined by man, connect concepts to something. Concept generalized an abstract idea of a person about an object or phenomenon. This gives the possibility of knowledge about the world, as well as these phenomena appear building elements of the conceptual system, processing the experience of a person, by summarizing information under categories and classes developed by society. The structure of the concept includes the forming concept, the main structural components such as information content, sensory image, and interpretation field, and characterizes by listing certain cognitive traits that relate to each of these structural components of the concept.
General assessments of some life phenomena, reflection in them peculiarities of his culture, a person gives with the help of paremias. Paremias are the personages of the unit of language that are extremely necessary for the communication of people. Due to these units, there is a transfer of some specific information, the transmission of some life situations, with the help of which, we understand the relationship between certain objects. Exists certain types of paremiological units. Knowledge about the paremias of a particular nation contributes to the understanding of their way of life, though, their language as a whole, since in them historically reflects the experience of the people, their ideas, and culture. Paremias make a speech special, expressive and original. In Russian, there are much more pairs with a somatism "heart". In English paremias, the concept of the heart in its primary meaning is found much more often. This somatism, as a subject of action, can describe the state of a person, his feelings, experiences, mood, pain Feel. In several Russian and English paremias, this somatism can be used in a metaphorical sense to convey human qualities, feelings, emotions.

\section{REFERENCES}

1. Wakk F. On somatic phraseology in the modern Estonian language. Abstract of the thesis. dis. Cand. philol. sciences. Tartu, 1964 . - P. 22.

2. Gak V.G. Comparative lexicology - M.: International relations, 1977. - p. 264.

3. Voroshilovo V.O. Somatisms in English and Russian paremiological pictures of the world. Final qualifying work. Ekaterinburg, 2016. - p. 47

4. Ismatullayeva, N. R. (2020). Expression of somatic physionimistic lacunas in chinese and uzbek languages. In Наука и инновации в XXI веке: актуальные вопросы, открытия и достижения (рp. 127-129). 
CURRENT RESEARCH JOURNAL OF PHILOLOGICAL SCIENCES 2(11):

94-99, November 2021

DOI: https://doi.org/10.37547/philological-crjps-02-11-21

ISSN 2767-3758

(C)2021 Master Journals

crossref do) 8: Google

Accepted25 ${ }^{\text {th }}$ November, 2021 \& Published $30^{\text {th }}$ November, 2021

5. Dictionary of English Language and Culture. Fifth Edition. - Harlow: Pearson Education Limited, 2002. 5. Johnson A. Common English Proverbs. - London, 1965.

6. Oxford Concise Dictionary of Proverbs. Oxford University Press, 1992.

7. Oxford Dictionary of English, 2nd edition, revised. - Oxford, New York. Oxford University Press - 2005. 8. The Oxford Dictionary of Proverbs. 5th ed. Oxford: Oxford University Press, 2008. 